\title{
Statistics for Rural Development Policy
}

\author{
Berkeley Hill \\ University of London, London \\ UK
}

\section{Introduction}

Modern rural development policy claims to be 'evidence-based', as indeed do many of the actions carried out by governments. While the rationale may be a mix of motives - typically those of equity, improving economic efficiency, and political economy - the details are often dependent on statistical information, particularly that coming from (or issued on behalf) the government's statistical authority. Official statistics typically carry a degree of quality assurance, and official statisticians are often keen to assert the accuracy, relevance and objectivity of what they generate.

Statistics can make a contribution at all stages of the policy process (see Figure 1), and this applies with particular potency to rural development policy. They can help throw light on the nature of the problems to be tackled (problem formulation), whether these be economic, social or environmental. While individuals or pressure groups can raise awareness of what, to them, are issues requiring intervention by government, public action is far more likely if the problems can be described using quantitative information, whether this be a decline in biodiversity, high levels of unemployment, low wages, homelessness, lack of social participation, or whatever. Statistics can assist in setting the objectives that have to be achieved to address the problems, such as increasing the percentage of the rural population with educational qualifications. They will be relevant to the choice and effectiveness of instruments employed, in particular by providing evidence on how they have performed on previous occasions. And statistics will form an integral part of evaluating the performance of rural development policy. In a well-designed system, statistics should be available that allows the extent of change from the pre-policy situation to be measured, and evaluators will be tasked with judging the extent to which any improvements in the situation can be attributed to the policy intervention and how much to other factors. Sometimes contextual factors (such as the state of the general economy) can change conditions in rural areas and be more influential than any policy actions targeted specifically at rural development, and official statistics can be useful in identifying such factors. A major issue that evaluators have to face is the establishment of the counter-factual - what would have happened had the policy actions not been taken. Statistics extending over time and space (particularly in control areas from which policy actions are absent) are immensely helpful in this respect and point to the additionality flowing from government intervention.

Figure 1 also portrays the system that provides the information necessary to serve the needs of decision-makers in rural development policy by collecting data (the 'data system') and 


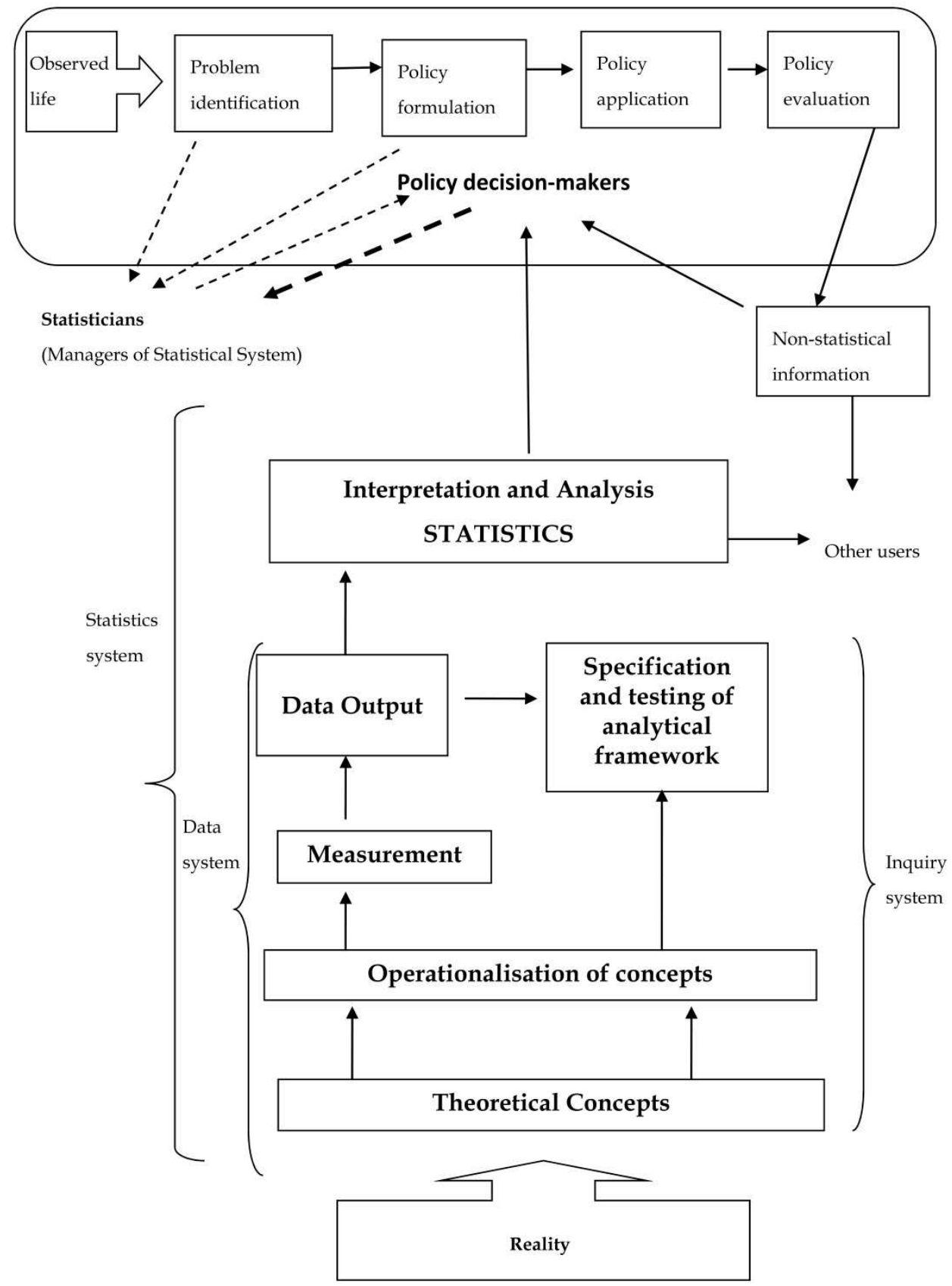

Source: Hill, B (2012) Understanding the CAP.

Fig. 1. The information system and the policy process 
analysing and interpreting. High-level policy staff cannot be expected to be totally familiar with the methods by which figures appearing in statistics have been obtained, including the limitations imposed by the sources of basic data or the strength of the inferences that can be drawn from the figures. Some digestion and interpretation by experts are usually required, and this is what turns the statistics into information. Only then can policy-makers use it as an input to their decision-taking.

Three distinct steps must be taken before data can be produced which purport to represent reality. In the terms used by the US agricultural economist and statistician Bonnen (1975, 1977), these are: (a) 'conceptualisation'; (b) 'operationalisation' of the concepts (definition of empirical variables), and (c) measurement, meaning the actual collection of data. Concerning the first, concepts central to policy (such as 'standard of living' of the rural population or 'biodiversity') often cannot be measured directly, and for the information system to be practical it is necessary to define proxy indicators (substitute measurable entities, such as the income of households resident in rural areas or numbers of farmland wild birds) which are as highly correlated with the object of enquiry as is possible. The choice of indicator will be governed by the objective for which the measurement is taking place. Sometimes there will be a trade-off between desirability and practicality. For example, consumption expenditure might be theoretically preferred as a means of operationalising the concept of standard of living but, because measurement is difficult to carry out, some form of income measure may be an acceptable substitute. While biodiversity ideally would involve counting all wildlife in an area, cropland bird numbers are far easier to assess and they reflect in an acceptable way the general state of biodiversity. Often there is a temptation to use indicators simply because the information exists, but this is likely to result in ineffective and inefficient policy actions. The starting point should be the object of policy that the information system exists to serve.

As will be seen below, a critical concept that needs to be made operational is that of a 'rural area'. Statistics for rural development are largely concerned with describing the conditions in areas that can be labelled as rural and comparing them with what is found elsewhere.

The collection and analysis of data (the measurement part of the data system) and its interpretation forms only part of the larger information system needed to service policy shown in Figure 1. In parallel with the direct servicing of policy there is generally a system of scientific inquiry (the inquiry system) which is designed to test the basic assumptions of the data system and its interpretation and analysis. Though civil servants who are concerned with generating statistics are often the most familiar with the details of their methodologies, they are also usually preoccupied with the difficulties of getting results calculated and making them available to users, often publishing to a regular timetable. They may well not have the resources to reflect on the suitability of their statistics for the purpose to which they are put, or the validity of the assumptions that lie behind them. This is where academics, outside commercial consultants or specialist review groups from elsewhere in the government service can be useful. They can ask the awkward questions that ultimately cause revisions in the provision of statistics, and thereby lead to an improvement in their quality and to the chance of better policy decisions based on them. In statistical areas that are relatively young, such as for rural development, the inquiry system may be of particular importance. Not least, questions can be asked such as 'what is a rural area?' and 'how does if differ from a non-rural area in the sorts of problems found there'. 


\section{Definition of rural and of areas deemed to be rural}

A key issue in the construction of statistics on rural areas for the purpose of assisting rural development policy is the method by which such areas are distinguished from non-rural areas. As will become apparent, this is context-sensitive and may reflect a number of factors.

There is an apparent dichotomy of views as to what sort of definition should be used. The UN Statistical Division argues that "given the variety of situations in the countries of the world, it is not possible or desirable to adopt uniform criteria to distinguish urban areas from rural areas [...]. Clearly, national statistical offices are in the best position to establish the most appropriate criteria to characterize urban areas in the respective countries" (UN, 2002 p. 106). In contrast, the OECD had originally agreed on a uniform single criterion (population density set at 150 inhabitants per $\mathrm{Km}^{2}$ ) for application in its members to separate urban and rural communities. Later, it added another criterion, which is the presence of an urban centre in the region, representing no less than $25 \%$ of the regional population.

This variety of approaches is part of a broader debate that encompasses:

1. The purpose for which the classification is required (which may be to reflect lifestyles in social, cultural and environmental terms, the functions performed by rural and urban areas, and public policy). For comparisons over time for the same country a national definition appropriate to the local conditions may suffice, but this may not be satisfactory where the interest is in making international comparisons.

2. The use of multiple and heterogeneous criteria to define rural areas, or a small reduced list, or even a single criterion. The last may be more easily implemented for comparing a multiplicity of countries but may omit some variables that are considered of local importance. In practice, a reduced list may be difficult to agree across national boundaries (Rodriguez, 2010).

3. Whether a dichotomic (rural/non-rural) or gradient approach should be used. Gradients permit the identification of different types of territories, from the distinctly rural (dispersed rural), going through intermediate categories, up to those that are eminently urban. (e.g. metropolitan areas).

In practice no single accepted official definition of "rural" exists among the richer industrialised countries; a survey in 2003 by the UNECE on Rural Development statistics highlighted the great number of definitions of rural then in use (UNECE, 2007; FAO, 2011)). In a number of them, rural is treated as a residual category, defined negatively in the sense of not being "urban" or "agglomerated" rather than being explicitly specified by its own properties. Urban definitions vary somewhat amongst countries, but in general urban areas are thought of as agglomerate with a high density of persons per square kilometre. The particular circumstances of some countries have led them to develop specific approaches to defining their rural areas. Nevertheless a definition put forward by the OECD (OECD 1994, $1996,2006,2007)$ is the most used at international level in territorial analysis. It is based on three criteria, combining features of population density, distribution and size. Details, and the typology of areas developed from their use, are described below.

In many cases, administrative and political subdivision of areas is based on geographical characteristics (rivers, mountains, coasts, etc.) and borders are designed based on them. 
However, in other cases administrative boundaries have been geometrically designed only on maps ${ }^{1}$. In the latter, new technologies based on remote sensing and digital photos allow the identification of rural areas with high degrees of approximation and enable them to be delimited at a small area scale (Smith et al., 2009). At the state of the art, the main limits to using this kind of solution stem from economic constraints and data availability.

Three parameters are critical when considering the definition of rural areas:

- The size of the territorial units and the level of geographic hierarchy;

- The criteria used to characterize the units at the respective levels;

- The quantitative thresholds used to define the boundary between rural and other areas or to establish the basis of setting a gradient between the various degrees or rurality (OECD, 1996).

\subsection{Size of territorial unit}

Among OECD countries, the basic territorial units used in national definitions of rural vary considerably in size, both with regard to population and area. For example, French Communes, which are the smallest administrative units in Europe, have an average population of 1,500 inhabitants and a surface area of 15 square kilometres, while English Local Authority Districts encompass on average 118,000 inhabitants in areas of more than 500 square kilometres. Counties, which in the United States are used as the basic building blocks for rural analysis, have an average population of 80,000 inhabitants and an average surface area of almost 3,000 square kilometres. In terms of area, these American Counties are much smaller in the East than in the West (OECD, 1996).

Within OECD countries, local and regional administrations perceive rural issues and implement rural policies mostly with reference to the local community level. In contrast, national, as well as supra-national administrations often deal with rural issues at the more aggregate regional level (OECD, 1996). A priori, neither level of territorial detail is more appropriate than the other. The "right" choice will depend on the analytical purpose or on the policy problems that have to be solved. In practice two levels of territorial hierarchy are used for rural classification and analysis.

- Local community level: At this level, the territorial grid is very detailed. It consists of small, though not necessarily the smallest possible, basic administrative or statistical units. Rural analysis is usually based on these local units when it is concerned with characteristics of "homogeneous" areas that can be classified as being either rural or urban. In practice, several levels of local units may be in use simultaneously where the policy interest goes down to small areas, such as where there are pockets of identifiably rural problems in close proximity to built-up areas. For example, the definition adopted in the UK for England and Wales starts from the characteristics and contexts of each 1 hectare squares in the national grid, this fine-grained approach being appropriate to the intermixing of what is perceived as rural areas (with distinct sets of policy problems) and urban settlementsin regions that, by the criteria used elsewhere, might not be classed as rural at all.

\footnotetext{
1 As in some ex-colonial African countries.
} 
- Regional level: Here the territorial grid is less detailed. The geographic building blocks are larger administrative units or functional zones, such as provinces or labour market areas. At this level, the emphasis of rural analysis is on functional relations and on the wider context in which rural development takes place. Usually these larger zones cannot be classified in terms of either rural or urban but as more or less rural, according to their degree of rurality.

Without this distinction between the two hierarchical levels of territorial detail it would be impossible to accurately describe the complexity of rural problems in their various national and regional contexts. A too narrowly designed scheme for territorial analysis would not properly reflect the diversity of analytical and policy perspectives concerning rural development both within and between countries.

\subsection{Criteria for designating areas as rural}

In terms of the criteria for the designation of "rural" areas, a wide range is found in use. For example, these may include:

- $\quad$ Size of population (total or agglomerated, absolute or relative);

- Population density (in relation to total or usable area);

- Commuting intensity (towards major cities or labour market centres);

- Share of agriculture (either in employment or in value added).

The choice of criteria used to identify rural areas is not independent of the size or hierarchical level of the territorial units to which they are applied. To define rural at the local community level, most OECD countries use a population size criterion. For larger functional or administrative regions, which in most cases will include at least some urban elements, criteria such as density and distance or others such as economic base are more commonly applied (OECD, 1996).

\subsection{Quantitative thresholds and gradients}

Even when the same criteria are used, the thresholds set for defining the boundary between rural and other categories vary considerably. For population, the size of the agglomerated units used by OECD Member countries varies between 1,000 (Australia and New Zealand) and 20,000 (Korea); 2,000 is the most common threshold. Where the share of agricultural employment has been used (though this is no longer applied in the OECD), the minimum considered for classifying an area as rural differed between 1.5\% (Luxemburg) and about $20 \%$ (Greece).

It is clear that the use of alternative definitions will not only yield different results with regard to the scope of rural areas (the percentage of the population resident there etc.) but will also create different pictures of their problems and perspectives. For example, if the share of "rural" population in France were to be calculated using the French, Italian, Spanish and Greek definitions, the respective results would be: $27 \%, 51 \%$, 30\% and $27 \%$. None of these definitions or their results, not even the French one, should be considered incontroversially as the "right" one (OECD, 1996).

Increasingly, a simple rural/non-rural binary classification is regarded as too crude, and gradients of rurality are preferred. Though these could be constructed using a single criterion, in practice combination of several factors is often employed. 
In summary, there is no single "correct" definition of rural. National definitions are continuously under debate and are in fact adjusted from time to time, reflecting, for example, changes in socio-economic and administrative structures or in mobility and communication (OECD, 1996).

\section{Typology of areas}

Given the primacy of the OECD approach to rurality, it is worth focussing on the classification of regions that it has generated, a typology that has been widely adopted for international studies. Since rural is about people and territory, the OECD selected population density, calculated as inhabitants per square kilometre, as the most relevant and practical criterion for identifying rural at the level of local communities. Population density reflects characteristics of settlement, distance and even intensity of communication and land use. It is a concept that is both intuitive to users and simple for providers of rural indicators to calculate. The OECD critical density was set at 150 inhabitants per square kilometres for Europe, North America, Australia and New Zealand. Setting thresholds always involves some arbitrary judgment. The decision to use 150 as the dividing line was, however, based on a series of empirical investigations including the implications of alternatives. Japan was treated as an exceptional case. Its population density is exceptionally high, being one of only three OECD countries where average national population density exceeds 300 inhabitants per square kilometre. Its settlement pattern is extremely diverse; while the population tends to be concentrated in certain parts of the country, other parts remain unpopulated. Mountains and islands create many natural barriers that limit accessibility. After intensive explorations, it was decided to use the same criteria and methodologies but to apply a higher density threshold of 500 inhabitants per square kilometre (OECD, 1996).

Under the OECD's working definition, rural areas are homogeneous in one dimension: their density is relatively low. This does not mean, of course, that their problems and perspectives are homogeneous. On the contrary, rural areas in the OECD are heterogeneous in several dimensions and it is an important task to understand this diversity further. The differences cannot, however, be explained only by the characteristics of the rural areas themselves. They often result from the type and intensity of relationship the rural communities have to other places in the wider region of which they are a part (OECD, 1996).

Once rural is fined, the performance of rural areas can be measured and compared by the use of indicators. With descriptions provided by the indicators, it may be of interest to create further problem- or policy-related typologies. This should not be confused, however, with the question of what "rural" is. It would be misleading to embed preconceived outcomes of rural analysis in the very definition of rural.

\subsection{OECD - An example of regional classification}

The typology of regions used by the OECD is an example of a gradient measure, though it starts from a dichotomy based on population density. The OECD territorial scheme distinguishes two levels of geographic detail: local communities and regions. It is based on three criteria, combining features of population density, distribution and size.

The first criterion identifies rural communities according to population density. A local community (small, basic administrative units appropriate to the country concerned) is 
defined as rural if its population density is below 150 inhabitants per square kilometre (500 inhabitants for Japan to account for the fact that its national population density exceeds 300 inhabitantsper square kilometre).

The second criterion classifies regions according to the percentage of population living in rural communities. Thus, a region is classified as:

- Predominantly Rural (PR), if more than $50 \%$ of its population lives in rural communities.

- Intermediate (IN), if between $15 \%$ and $50 \%$ of its population lives in rural communities.

- Predominantly Urban (PU), if less than $15 \%$ of its population lives in rural communities.

The third criterion is based on the size of the urban centres. Accordingly:

- A region that would be classified as PR on the basis of the general rule is classified as IN if it has an urban centre of more than 200000 inhabitants (500,000 for Japan) representing no less than $25 \%$ of the regional population.

- A region that would be classified as IN on the basis of the general rule is classified as PU if it has an urban centre of more than 500000 inhabitants $(1,000,000$ for Japan) representing no less than $25 \%$ of the regional population.

As the geographic and population size of a "region" can vary significantly both within and between countries, the OECD has also established a systematic classification of territorial units within each Member country. The classifications, and therefore the regional typology, are based on two Territorial Levels (TL). The higher level (TL2) consists of about 300 macroregions while the lower level (TL3) is composed of about 1,700 micro-regions (OECD, 2009).

The criterion used to create the typology at the regional level is the share of the population of the region living in rural communities. Thus, the typology reflects the degree of rurality of the whole region (OECD, 1996). In 1990, about a third of the OECD population lived in rural communities that covered over $90 \%$ of the OECD territory. About a quarter lived in predominantly rural regions (OECD, 1994).

The OECD typology of regions has been refined recently to take into account remoteness of rural regions: the extended typology comprises remote rural regions, rural regions close to a city, intermediate and predominantly urban regions. It has been developed jointly by DG Regio of the EU Commission and OECD (OECD, 2010), who suggest including a criterion on the accessibility to urban centres (Ruiz and Dijkstra, 2010). The results show a clear distinction between remote rural regions and rural regions close to a city in terms of declining and ageing population, level of productivity and unemployment. This extended typology, which includes a measure of distance from cities for the population living in a rural area, is applied to North America and Europe. The authors aim to extend it in the future to the other OECD countries and evaluate the feasibility to apply a similar method to non OECD countries.

\subsection{Rural area typology in England and Wales (UK)}

In contrast to the OECD's regional typology, an example of a much more detailed classification is provided by the system applied in England and Wales (United Kingdom). This enables Census Output Areas (CAOs), which are units connected to the ten-yearly population census, containing of approximately 125 households, to be placed into one of 
eight different area types, as shown below, according to its settlement type and context. The process by which COAs are allocated involves using a grid of 1 ha cells and a "moving window" that examines both the population density of that cell and the characteristics of its surrounding area. Thus two characteristics, morphology and context are at the basis of the definition. It should be noted that "rural" comprises the six types that are not explicitly "urban".

The core classification of COAs has been adapted for larger geographical units that comprise multiple COAs, including the 354 Local Authority Districts (LADs) which are the unit on which much official data are collected. These are allocated to one of six broad classes based upon the number and proportion of their populations in the main settlement types derived from the "local" rural definition. Three classes are predominantly urban in nature ("Major Urban", "Large Urban" and "Other Urban") comprising 176 LADs in all. The main rural types, of which there are 178, are called "Significant Rural", "Rural-50" and "Rural-80", identified by the proportion of people in rural settlements of all kinds: "Rural-80" LADs have between 80 and 100 percent of inhabitants in rural settlements, "Rural-50" LADs have more than 50 percent, whilst "Significant Rural" LADs have more than the national average of 26 percent. These broad classes can, if required, be further broken down into the different types of specifically rural settlement they contain. Most "Rural 80 " LADs, for example, have a predominance of people living in villages.

\begin{tabular}{lc}
\hline \multicolumn{1}{c}{ Settlement type } & Context \\
\hline Urban $>10,000$ & Less sparse \\
Town and fringe & Less sparse \\
Village & Less sparse \\
Hamlet and isolated dwellings & Less sparse \\
\hline Urban $>10,000$ & Sparse \\
Town and fringe & Sparse \\
Village & Sparse \\
Hamlet and isolated dwellings & Sparse \\
\hline
\end{tabular}

Source: CRC (2007), Defining rural England.

Table 1. England: Classification of Census Output Areas by Settlement Type and Context

A key point for both the OECD regional and the England and Wales detail classification is that they apply universally in the countries where they are applied. In other words, the rural areas are a subset of a general disaggregation of the national picture, and whatever indicators are generated for rural areas will have parallels for non-rural areas. Thus any use of the term 'rural statistics' is misguided, as there is nothing unique about their rural nature. Rather, it is better to refer to 'statistics for areas that have been classed as rural'.

\section{Indicators for rural areas - Choice of content coverage}

Statistics on rural development are used by policy makersand private sector decision makers to inform their decisions regarding a variety of important issues. It is these issues that drive the choice of indicators to be developed and the core data to be collected. Many of 
today's critical issues are not new, but they have increased in importance, have come to be framed differently or have been newly recognized. One important finding of the Global Strategy to Improve Agricultural and Rural Statistics (UN, 2010), which relates to countries at all stages of economic development, was the considerable overlap between the issues identified by different stakeholders. Many users expressed the need for new and improved indicators on prices, energy and biofuels, agricultural environments, climate change, trade, water, land, soils, household consumption, food security, socio-economic data, economic accounts, management of natural disasters and fisheries. They also had high expectations for geospatial and remote sensing data and expressed the need for improved integration and for more accessible and searchable databases. The most critical issues are not independent from each other, and much of the data are needed for more than one indicator. The goal of the Global Strategy is to capture the interrelationships of these emerging issues and to ensure that appropriate indicators are defined and underlying data provided. This points to a major problem with current statistics; many of the issues have been considered in isolation, and this does not allow the cross-cutting analysis that is now needed.

When considering what indicators should be available special mention must be made of the relationship between statistics on agriculture and rural development. It is clear that agriculture as an activity is an identifying factor in making an area rural. While farming and forestry dominate land use in most countries, and therefore are important in determining countryside appearance and its biological content and diversity, in OECD countries these sectors typically represent only a small (and declining) share of economic activity taking place there and of the income of the people who live there. Much more comes from the other sectors, and statistics that attempt to describe the economic picture in rural areas must move beyond agriculture and farmers to embrace the other residents, entrepreneurs and business units located there. While agricultural statistics are relatively well-established, those for rural areas in general are far more recent and less comprehensive.

It is also necessary to point out that 'rural development' can be perceived in various ways, and thus the statistics needed to service it will vary. For example, in the EU rural development policy has a strong environmental strand because of the way that it has developed as a part of the Common Agricultural Policy, and this sits alongside the economic and social aspects. Furthermore, as the legislation that enables sums to be drawn from the European Union General Budget specifies a list of activities that can be supported (in broad terms relating to the competitiveness of agriculture and forestry, the environment, and a subset of issues that affect the quality of life in rural areas), rural development policy does not cover things like rural housing, access to health and education services, or transport and communications infrastructure for the general population. Consequently, statistics needed to service EU rural development policy do not cover many issues that are important to the residents of rural areas, though such statistics may be provided to assist in the operation of EU regional policy and national policies for education, healthcare and so on. Conversely, in the US rural development focuses on economic issues (mainly incomes and employment). While there is an increasing concern with environmental conditions, climate change and so on, these are seen as part of environmental policy rather than rural development (Blandford and Hill, 2008).

The selection of indicators for rural areas must be guided in part by the principles applicable to any set of indicators (relevance, accuracy, sensitivity, timeliness, accessibility etc) as 
articulated by many international statistical bodies and set out by the FAO when creating its the CountrySTAT database. But it must be driven even more by characteristics that are specific to rural development. There are three basic aspects which any reasonable assessment of conditions in rural areas and trends must take into account:

- Territory: Rural development is a spatial concept. It deals with territorial differences in problems and perspectives, options and opportunities. Such differences can be considered positively (diversity) or negatively (disparities). In either case, the territorial distribution determines the overall performance and viability of economic, social and environmental systems as well as the effectiveness and efficiency of related policies.

- Themes: Rural development is a multi-sectoral concept. It is concerned with a wide range of demographic, economic, social and environmental issues. It stresses the importance of a cross-sectoral perspective and often provides an appropriate framework for the horizontal integration of various activities and policies.

- Time: Rural development is a dynamic concept. It is concerned not with the mere passing of time but with concrete, historical dynamics which are reflected in changing technological options, economic structures, or social attitudes and perceptions.

Any set of indicators for rural areas, therefore, has to provide information on a variety of economic, societal and environmental subjects. It has to do so in a territorially differentiated manner and it should be capable of reflecting changes over time (OECD, 1996). Within the themes, a statistical reduction of strongly correlated indicators is encouraged to reduce overlapping information (where closely similar indicators tell the same story), to further economy in the provision of public services, and to avoid the negative effect of excess information that produces 'noise' for users and potentially reduces their understanding (Gianfaldoniet al., 2009).

In terms of what themes indicators should attempt to depict, clearly this depends on the nature of the problem and policy in hand. The observation of rurality can be done from several perspectives, suggested by different theories of development, which in turn lead to corresponding themes of interest. For example, if the focus is on the development process, the discussion on indicators might start from a framework for understanding "sustainable livelihoods" as suggested by the UK's Department for International Development (DFID). DFID defines livelihood as the combination of "the capabilities, assets and activities required for a means of living" 2 .

Within this livelihood context the core analytical framework starts from the so-called asset pentagon, which contains the following five categories:

1. natural capital

2. financial capital

3. human capital

4. physical capital

5. social capital

${ }^{2}$ Introduction to the Sustainable Livelihoods Approach
(www.livelihoods.org/info/info_guidancesheets.html) 
Communities and regions achieve desired outcomes by applying strategies that exploit these assets. Indicators or statistics on strategies are difficult to conceptualize and, typically, the strategy that works for one community or region will not be appropriate for another. However, some indicators or statistics may be proposed that measure the potential for development, requiring a further (sixth) category:

6. The capacity of the community/region to generate and to implement strategies .

International organisations have lists of indicators that they consider appropriate and recommend for statistic on rural development (World Bank, FAO, OECD, European Commission - all reviewed in FAO, 2011). The list suggested by the OECD is given in Table 2. The European Commission uses a set when compiling its annual reports on rural development in the EU (Commission, 2009); these are somewhat narrower than the OECD suggested coverage, reflecting the baseline indicators set out for actions that are supportable under the Rural Development Regulation (for the period 2007-13 this is Council Regulation (EC) 1698/2005) that implements the Pillar 2 (rural development element) of the Common Agricultural Policy.

\begin{tabular}{|c|c|c|}
\hline Demographic statistics & Regional accounts & Innovation \\
\hline $\begin{array}{l}\text { Population by age and sex } \\
\text { Average population } \\
\text { Regional surface } \\
\text { Population density }\end{array}$ & $\begin{array}{l}\text { GDP } \\
\text { Per capita GDP } \\
\text { GVA by sector }\end{array}$ & $\begin{array}{l}\text { R\&D Expenditures by } \\
\text { performing sector } \\
\text { R\&D Personnel by sector } \\
\text { Educational attainments of the }\end{array}$ \\
\hline Social indicators & Regional labour markets & \\
\hline $\begin{array}{l}\text { Age-adjusted mortality rate } \\
\text { Number of physicians } \\
\text { Number of physicians per } 1000 \\
\text { inhabitants } \\
\text { Crime } \\
\text { Volume of municipal waste } \\
\text { Volume of municipal waste per } \\
\text { capita } \\
\text { Number of private vehicles } \\
\text { Number of private vehicles per } \\
100 \text { inhabitants } \\
\text { Voter turnout rate }\end{array}$ & $\begin{array}{l}\text { Labour force by sex } \\
\text { Employment by sex } \\
\text { Employment by industry } \\
\text { Unemployment by sex } \\
\text { Unemployment rate } \\
\text { Participation rate } \\
\text { Long term unemployment } \\
\text { incidence } \\
\text { Business statistics } \\
\text { Total number of establishments } \\
\text { by industry } \\
\text { Number of employees by } \\
\text { industry }\end{array}$ & $\begin{array}{l}\text { education } \\
\text { technoymelogy sectors } \\
\text { High and medium high- } \\
\text { technology manufacturing (as } \\
\% \text { of total manufacturing) } \\
\text { Knowledge intensive services } \\
\text { (as \% of total services) } \\
\text { High and medium high- } \\
\text { technology manufacturing (as } \\
\% \text { of total employment) } \\
\text { Knowledge intensive services } \\
\text { (as \% of total employment) } \\
\text { Percentage of households with } \\
\text { access to broadband }\end{array}$ \\
\hline
\end{tabular}

Source: OECD website

(http://www.oecd.org/document/62/0,3343,en_2649_34413_36878718_1_1_1_1,00.html)

Table 2. OECD's basic rural development indicators classified by themes

\subsection{Sets of stage-related indicators to evaluate rural development policies}

A prominent example of the use of statistics is found within the EU's Common Monitoring and Evaluation Framework (CMEF) that applies to Rural Development Programmes 
operated under the Common Agricultural Policy (European Commission, 2006). Though the CMEF uses a particular terminology, the principles it embodies, including its sets of indicators, are of general applicability.

Statistics are used to set out situations in rural areas before policy intervention is undertaken, that is to establish a baseline. This information also feeds into an analysis of the Strengths, Weaknesses, Opportunities and Threats (SWOT) that underlies the rationale for policy action. As noted previously, not all aspects of rural areas and their development are covered; the range is restricted to the forms of support that can be actioned under the Rural Development Regulation. Under the CMEF two types of baseline indicator are encountered. The first (called objective-related) directly relates to the issues under concern and on which rural development policy focuses (for example, the incomes and productivity of rural residents). The second type (context-related) relates to factors that are anticipated to affect the issues under concern in addition to the policy intervention itself (such as the pattern of land use and the proportion of the working population in rural areas). As policy actions are implemented there will be interest in how these indicators have moved from their initial levels. Evaluators will be concerned with the extent to which interventions have been the cause of shifts in levels or of alterations in trends.

However, evaluation of rural policy also involves indicators that measure the direct resource use and immediate impacts of interventions. While rural statistics are not likely to be concerned with the inputs or outputs of policy actions (for example with the cost of providing vocational training or the number of people trained), they will be increasingly affected by indicators of results (such as the gross number of jobs created) and the impacts of the interventions (the net number, once other factors such as displacement and multipliers have been accounted for $)^{3}$. Evaluators will need to examine how the baseline indicators have changed over the life of a rural development policy and to explain how many of the observed changes can be attributed to the policy interventions that have taken place. Various techniques have been suggested by which this may be achieved (e.g. European Commission, 2010), though the less-than-ideal circumstances in which evaluation typically takes place (including data deficiencies) means that a degree of subjective judgement is always present. Thus while baseline indicators, to which statistics for rural areas bear a close relationship, are important to evaluating the performance of rural development policy, they do not provide a complete description of the process by which policy interventions work and how its performance can be assessed. Other information and process-linked indicators of inputs and outputs will also be needed.

\section{Data issues}

Data are essential for the provision of statistics for rural development. Of the three legs on which statistics stand (the design of statistical methodology, its application and interpretation, and the provision of data), the last is often the poor relation in terms of the

\footnotetext{
3 The indicators at the various stages of policy interventions are a feature of the Logical Framework Approach (LFA), a process and a tool often used in developing countries to help strengthen analysis and design during formulation, implementation, evaluation and audit. In the LFA context, the term "outcome" is used in place of "result".
} 
attention paid to it and the esteem in which its practitioners are held. Yet without data that are of good quality the other parts of the information system soon lose their effectiveness.

The supply of data is essentially something that has to be tackled at a national level. While there may be international obligations to provide data, especially for Member States of the EU to meet the statistical commitments of membership, the cost of doing so falls largely on the individual country. Data for rural areas come from a variety of sources. These include administrative records (such as the beneficiaries of welfare payments, educational attainment, health care services), taxation data, official censuses and surveys (including population censuses, labour force surveys, household budget surveys and panels that trace developments in incomes and living conditions over time, agricultural surveys), and special studies. The use of many of these for statistical purposes will often not have been considered in their design, and statisticians will be challenged to integrate them in a meaningful way. To an increasing extent links using geo-referencing or personal identification numbers (or both) are helping to facilitate their assembly into integrated datasets for specific and identified small areas. Some countries, such as those in Scandinavia, have a history of being able to integrate various datasets (population censuses, agricultural censuses, taxation records etc.) and this can be a highly efficient way of delivering statistical information for rural residents. However, such bringing together is sometimes technically difficult because, for example, the lack of a common definition of what is a rural area or of the household unit. In some countries there are legal obstructions to combining datasets or it is banned. The use of taxation data may be particularly sensitive in this regard..

In OECD countries there are some surprising data gaps; for example, though diversification by farm families is frequently encouraged as a way of promoting rural development, the EU has no system in place that can provide data on overall incomes of farm households and the way that non-agricultural activities are contributing to their total earnings.

The World Bank has recognised that, while a problem of data availability to construct indicators may be found in OECD countries, it is most acute in developing countries. Not only is there a problem with the quality and reliability of rural data in many developing countries but vital data may simply not exist there. Even when data are collected, most are aggregated at the national level with no possibility of breaking this down to urban-rural and regional levels. Recently, a joint team - composed by staff from the Global Donor Platform for Rural Development, the World Bank and FAO - has published the Sourcebook of indicators for monitoring and evaluation (MEE) agriculture and rural development in less-than-ideal conditions (GDPRDet al., 2008). This work provides a number of workable approaches for designing an M\&E system that would be of great relevance to different rural development activities, projects and programmes, and degrees of data availability. The construction of the GDPRD rural development statistical framework was based on three main requirements: comparability, availability and relevance - qualities familiar from the early parts of this chapter. A set of 19 priority indicators have been identified in order to allow international comparisons. Though primarily aimed at developing countries, there is much that is relevant universally.

\section{Acknowledgment}

The author gratefully acknowledges that much of the material contained here is condensed from the 2011 edition of the Wye Group Handbook Statistics on Rural Development and 
Agricultural Household Income, of which he was a main author and general editor. This is to be made available on the FAO website later in 2011.

\section{References}

Blandford, D. and Hill, B. (eds) (2008), EuroChoices Special Issue comparing EU and US Rural Development Policies. Volume 7, number 1.

Bonnen, J. T. (1975), 'Improving Information on Agriculture and Rural Life'. Amer. J. agric. Econ., 57, 753-63.

Bonnen, J. T. (1977), 'Assessment of the Current Agricultural Data Base: an Information System Approach.' in Martin, L. R. (1977), A Survey of Agricultural Economics Literature. - Volume 1. Traditional Fields of Agricultural Economics 1940s to 1970s. - Vol. 2. Quantitative Methods in Agricultural Economics, 1940s to 1970s, University of Minnesota Press, Minneapolis.

CRC (2007). Defining rural England. Commission for Rural Communities.

European Commission (2009). Rural Development in the European Union: Statistical and Economic Information Report 2009. Directorate-General for Agriculture and Rural Development, Brussels.

European Commission (2006). Handbook on the Common Monitoring and Evaluation Framework..DG-Agriculture and Rural Development, Brussels.

European Commission (2010). Working Paper on Approaches for assessing the impacts of the Rural Development Programmes in the context of multiple intervening factors. European Evaluation Network for Rural Development. The European Commission, Brussels.

FAO (2011). Wye Group Handbook: Statistics on Rural Development and Agricultural Household Incomes. United Nations Food and Agriculture Organisation, Rome. (to be available on the FAO website).

GDPRD, FAO, World Bank (2008). Tracking results in agriculture and rural development in lessthan-ideal condition. A sourcebook of indicators for monitoring and evaluation. FAO, Rome.

Gianfaldoni, V. and Pizzoli, E. (2009). Social Well-Being, Economic Development and Sustainability in Rural and Urban Areas: A Comparison of Indicators. Second Wye City Group Meeting on Statistics on Rural Development and Agriculture Household Income, Rome.

Hill, B. (2012). Understanding the CAP. Earthscan / Routledge, London.

OECD (1994). Territorial Indicators of Employment.Focusing on Rural Development. OECD, Paris. http://www.oecd.org/findDocument/0,2350,en_2649_34419_1_119699_1_1_37429, 00.htm

OECD (1996). Creating rural indicators for shaping territorial policy. Organisation for Economic Co-operation and Development, Paris.

OECD (2006). The New Rural Paradigm: Policies and Governance. Organisation for Economic Co-operation and Development, Paris. ISBN 9264023917.

OECD (2007). OECD Regions at a Glance 2007. Organisation for Economic Co-operation and Development, Paris.

www.oecd.org/agriculture/policies/rural

OECD (2009). OECD Regions at a Glance 2009. OECD, Paris.

www.oecd.org/regional/regionsataglance 
OECD (2010). Refinement of the OECD regional typology: Economic Performance of Remote Rural Regions. OECD, Paris. www.oecd.org/dataoecd/41/56/45511797.pdf)

Rodríguez, A.G. (2010). On the Pertinence and Implications of Modifying the Criteria to Separate Rural from Urban in Latin America. English version of Chapter 4 in Dirvenet al.(2010), Hacia una nueva definición de "rural" con fines estadísticos en América Latina. Documento de Proyecto, Unidad de Desarrollo Agrícola/CEPAL, Santiago, Chile.

Ruiz, V. and Dijkstra, L. (2010). Refinement of theOECD regional typology: economic performance of remote rural regions. Third Wye City Group Meeting on Statistics on Rural Development and Agriculture Household Income, Washington.

Smith, J., Bédard, F. and Dobbins, R. (2009). Use of remote sensing in combination with statistical survey methods in the production of agricultural, land use and other statistics: Current applications and future possibilities. Second Wye City Group Meeting on Statistics on Rural Development and Agriculture Household Income, Rome.

UN (2002). World Urbanisation Prospects: The 2001 Revision. United Nations, New York.

UN (2010). Global Strategy to Improve Agricultural and Rural Statistics. Report of the Friends of the Chair on Agricultural Statistics, United Nations Economic and Social Council Statistical Commission. Forty-first session, 23-26 February 2010.

UNECE (2007). The Wye Group Handbook: Rural Households' Livelihood and Well-Being Statistics on Rural Development and Agriculture Household Income. United Nations Economic Commission for Europe, Geneva. (also available on the FAO website). 


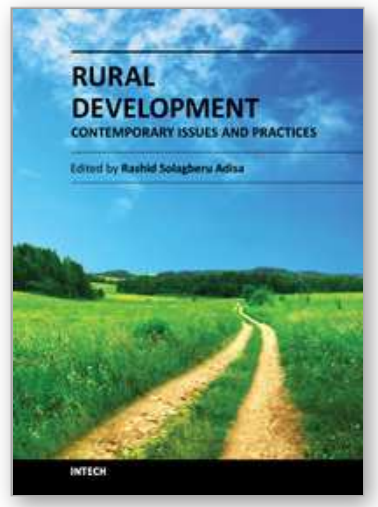

\author{
Rural Development - Contemporary Issues and Practices \\ Edited by Dr. Rashid Solagberu Adisa
}

ISBN 978-953-51-0461-2

Hard cover, 408 pages

Publisher InTech

Published online 20, April, 2012

Published in print edition April, 2012

Development of rural areas has witnessed increasing attention globally, especially over the past three to four decades. The highpoint in the renewed global interest in the development of rural people and their environment was reached with the setting of the Millennium Development Goals (MDGs) in the year 2000. All of the set goals are basically rural development goals. With less than four years to the deadline for the achievement of the MDGs, it is almost certain that the goals are far from being achieved in, especially, most developing countries for whom the MDGs were essentially set. The struggle thus continues for rural development. As long as problems of poverty, disease, illiteracy, unemployment, poor infrastructure, environmental degradation and others persist (or increase) in rural communities, better and more resultoriented solutions to perennial and emerging problems of rural communities would be required. But rural development, in spite of the variations in thresholds of rurality among nations, is not exclusively a Third World or \&lsquo;developing countries\&rsquo; process, owing to its multi-dimensionality. It is a global phenomenon that obviously requires global strategies. This book not only looks at rural development from its multidimensional perspectives, it is also a product of the experiences and expertise of distinguished scholars across the continents. Aiming to provide a comprehensive single volume that addresses salient issues and practices in rural development, the book covers themes ranging from sustainable agriculture, biodiversity conservation, strategic environmental assessment, renewable energy, rural financial resources, assessment of protected areas to statistics for rural development policy. Other subject matters covered by the book include social marginality, land use conflict, gender, cooperatives, animal health, rural marketing, information and communication technology, micro-business, and rural economic crisis. The book is thus an invaluable source of useful information on contemporary issues in rural development for researchers, policy makers, and students of rural development and other related fields.

\title{
How to reference
}

In order to correctly reference this scholarly work, feel free to copy and paste the following:

Berkeley Hill (2012). Statistics for Rural Development Policy, Rural Development - Contemporary Issues and Practices, Dr. Rashid Solagberu Adisa (Ed.), ISBN: 978-953-51-0461-2, InTech, Available from: http://www.intechopen.com/books/rural-development-contemporary-issues-and-practices/statistics-for-ruraldevelopment-policy

\section{INTECH}

open science | open minds 


\section{InTech Europe}

University Campus STeP Ri

Slavka Krautzeka 83/A

51000 Rijeka, Croatia

Phone: +385 (51) 770447

Fax: +385 (51) 686166

www.intechopen.com

\section{InTech China}

Unit 405, Office Block, Hotel Equatorial Shanghai

No.65, Yan An Road (West), Shanghai, 200040, China

中国上海市延安西路65号上海国际贵都大饭店办公楼 405 单元

Phone: +86-21-62489820

Fax: $+86-21-62489821$ 
(C) 2012 The Author(s). Licensee IntechOpen. This is an open access article distributed under the terms of the Creative Commons Attribution 3.0 License, which permits unrestricted use, distribution, and reproduction in any medium, provided the original work is properly cited. 